are likely to become available in Britain in 1956. It is emphasized by the Council that the vaccine is at present available only for these limited purposes, and that applications for inoculation cannot be entertained.

\section{Gravity Survey in the South Atlantic and Indian Oceans}

Gravity surveys are to be made during a training cruise by H.M. Submarine Acheron to Trincomalee via the Cape of Good Hope and back through the Mediterranean. Observations will be made by Lieut. J. C. Harrison, R.N.V.R., a 25-year-old National Service officer who, after taking his degree at Cambridge, went to the University of California. From the coast of California he has recently made some half-dozen cruises in U.S. submarines in the course of which gravity surveys have been made. Three gravity surveys organized by the Department of Geodesy and Geophysics at Cambridge have previously been made in British submarines in Home and Mediterranean waters. They have been organized through the Defence Services Research Facilities Committee of the Royal Society. The forthcoming grevity survey will be in the South Atlantic and Indian Ocean, and it is in response to a resolution of the General Assembly of the International Union of Geodesy and Geophysies requesting all maritime powers to carry out so far as possible soundings and gravity measurements in those of the oceans which have not yet been explored. The Admiralty will be paid for the additional expenses resulting from the scientific work. The Acheron was expected to leave Portsmouth on April 20, and to return to the United Kingdom in about six months.

\section{The Future of the Norfolk Broads}

$\mathrm{I}_{\mathrm{N}}$ replying to $\mathrm{Mr}$. John Parker in an adjournment debate in the House of Commons on March 25, when the question of making the Norfolk Broads into a national park at an early date was raised, Mr. Hugh Molson, the joint parliamentary secretary to the Ministry of Transport and Civil Aviation, gave a useful statement of the present position. He stated that the matter had been considered by the National Parks Commission, set up in December 1949, which early reached two fundamental conclusions: first, that it would be unwise to designate the area without a clear prospect that the deterioration to which Mr. Parker referred could be halted; and secondly, that although the Act permits the Minister to pay a 100 per cent grant on waterways expenditure, it is reasonable that local interests, who will benefit from the work done, should contribute.

In April 1951 the National Parks Commission asked the then Minister for Housing and Local Government whether it could count on a contribution of, say, $£ 30,000$ a year from the Treasury towards the work that would be required. An extensive survey carried out by one of the Ministry's engineering inspectors in the following summer confirmed that the expenditure to make a thorough job would not be less than $£ 750,000$ and might well be $£ 890,000$ for a period of twenty years with considerable maintenance costs, and that not less than four million tons of silt would require to be deposited upon the adjoining agricultural land. After considering this report, the Ministry, in January 1953, informed the Commission that any scheme involving works on this scale must, for the time being, be regarded as out of the question. Mr. Molson added that the Nature Conservancy, and probably also the landowners, are opposed to the dumping of large quantities of silt upon the banks of the Broads, and the Ministry of Agriculture and Fisheries is concerned as to the effect of such dumping on fertility.

Mr. Molson said that he was not able to anticipate the Chancellor of the Exchequer's promised statement regarding the availability of the Land Fund for such purposes. There are, he thought, three possibilities. One is to designate the Broads as a national park and undertake the expenditure involved in the large-scale dredging. Secondly, the area could be designated in the hope that a certain amount of money might be available for some of the purposes required, and this the Commission would clearly consider. The third possibility is to leave matters as they are so far as the Government is concerned. Mr. Molson understood that local interests are doing some work at the present time and that some amenities which are of the greatest importance are being preserved. The matter is constantly under consideration by the National Parks Commission, which is in touch with the Ministry of Housing and Local Government on the subject, and technical difficulties make it uncertain at least whether the work could be satisfactorily carried out even if a large sum of money were available. In opening the debate, Mr. Parker cited the recent estimate that at least half an inch of deposit is added to the bottom of every Broad each year, that deterioration has proceeded much more rapidly in Broads closed to the public than in those still open, and that there is also some silting up of the through waterways. The 2,600 acres of open water in the Brosds at the time of the Hobhouse Committee's Report is to be compared with three thousand acres fifty years ago and four thousand acres a hundred years ago.

\section{First Forest Park in Northern Ireland}

The first forest park in Northern Ireland, Tollymore Park in County Down, will be open to the public from May 1. The Park, which covers an area of about twelve hundred acres, is beautifully situated at the foot of the Mourne Mountains, and the River Shimna runs through the forest, which was formerly owned by the Earl of Roden. The decision to create the Park has been taken under the Forestry Act (Northern Ireland) 1953, which empowers the Ministry of Agriculture to declare that any land owned by the Ministry shall be treated as a forest park, to which the public shall have access in accordance with by-laws. The Ministry proposes to open the Park to camping parties from youth organizations, and there will also be parking sites for about twenty caravans.

\section{Russian Comfrey as a Crop}

SINCE Russian comfrey (Symphytum peregrinum) was first introduced into Great Britain in 1870, its agricultural value has been a matter of some controversy. To secure more definite information regarding cultivation of this crop, and the methods for conserving and feeding it, a number of trials were carried out in 1954 in Great Britain and overseas under the rgis of the Henry Doubleday Research Association, Bocking, Braintree, Essex. The conclusions of these trials have been published by the Association under the title of "Russian Comfrey Report No. 1: The 1954 Research Results", by Lawrence D. Hills (pp. $36+5$ plates; $1955 ; 3 s$ ). The plant is a perennial, and, when established, will 